\author{
Marija Milojković* \\ University of Belgrade \\ Faculty of Philology \\ Belgrade, Serbia
}

\title{
CONTEXTUAL PROSODIC THEORY APPLIED TO ENGLISH-SERBIAN POETIC TRANSLATION
}

\begin{abstract}
The paper focuses on two rival translations of Shakespeare's Sonnet 129 into Serbo-Chroatian (Hlebec 1987). The translator provides Version A, which faithfully conveys the stylistic nuances of the original, and is aimed to be appreciated by a sensitive reading public, and Version B, which the translator calls "adulterated", but believes to be more accessible to a wider audience. However, he feels that Version B is "somehow more likeable" (Hlebec, personal communication). This impression was shared by all seven educated native speakers of Serbian consulted, among whom were three third-year students of English. Using Contextual Prosodic Theory and the Corpus of Contemporary Serbian, the paper sets out to explain this impression. The results suggest that syntactic patterns in Version A, being closer to the English original than in Version B, may impede comprehension, and that certain lexical items may not chunk the same states of affairs in Serbian as their English equivalents do in English. A representative poetry corpus must be created in order to verify Hlebec's view (personal communication) that syntax employed in Version A is characteristic of Serbian poetry and therefore appropriate in poetic translation.
\end{abstract}

Key words: corpus stylistics, Contextual Prosodic Theory, collocation, semantic prosody, corpus-derived subtext, poetic translation

\footnotetext{
E-mail address: marija.milojkovic@fil.bg.ac.rs
} 


\section{Introduction}

Louw's Contextual Prosodic Theory (CPT) emerged out of its originator's involvement with the COBUILD (1998) project, whose aim was to create the first corpus-based English dictionary. Having at his disposal a 22million-word corpus, Louw came up with the idea of a reference corpus, to be used for a more nuanced interpretation of poetic texts. This is how in 1987 at Hilda's College, Oxford, Louw launched the discipline of corpus stylistics (Louw and Milojkovic 2014: 263), which was to employ large language corpora as a reference norm against which to interpret semantic nuances in individual texts. The principle behind this interpretation was that the most frequent collocates of the node in the reference corpus shed additional light on its semantics, which later became known as the semantic prosody of the node (Louw 1993). Initially focusing on lexis only, this principle was later transferred to grammar, suggesting that a grammar string's logical semantic prosody, or its corpus-derived subtext, consisted of its most frequent lexical variables. ${ }^{1}$

Since a large and representative corpus of a language is a reliable source of additional information on the node's semantic aura, CPT may be used to facilitate the process of translation, as well as to adjudicate the success of particular translations (Louw and Milojkovic 2016). It stands to reason that the semantic aura of the author's expression ought to be reasonably well represented in the translation. Albeit time-consuming, this interpretative strategy is a valuable addition to translation methodology (Wang and Humblé 2018: 551), particularly when it comes to famous poets whose works may have been a source of difficulties for many a translator.

In its subsequent sections, this paper will give an account of how CPT may be used to compare two rival translations. In addition to semantic prosody and subtext, it will make use of the term states of affairs (Wittgenstein 1922), which are created by the node in the reference corpus, and which yield themselves to description based on Firth's definition of the context of situation (1957: 182).

1 For a detailed account of corpus-derived subtext and Louw's Contextual Prosodic Theory, see Louw and Milojkovic $(2014,2016)$ and Milojkovic (2013). 


\section{Comparing rival translations}

\subsection{Translations A and B of Sonnet 129}

In his paper Prevođenje Šekspirovog soneta 129 na Srpskohrvatski jezik ("Translating Shakespeare's Sonnet 129 into Serbo-Croatian", Hlebec 1987), Professor Boris Hlebec of the University of Belgrade ${ }^{2}$ argues that more care should be taken when translating Shakespeare's sonnets than is usually the case. The translator should take into account the wish of the reading public to appreciate as many Shakespeare's stylistic nuances as possible - the density of language, the phonological associations, the alliteration and assonance, the repetitions, symmetries, parallelisms and regularities. One should not confine oneself to transferring the narrative and descriptive essence of the sonnet, unless the target reading public is not "sensitive to the poetic function", claims the author (Hlebec 1987: 135). To this end, Hlebec studies Jacobson's and Johns's (1970) comments on Sonnet 129 as well as Culler's (1975) references to these authors, adds his own observations and translates Sonnet 129, retaining as many key stylistic aspects as possible - the compression of thought, the symmetries of morpho-syntax, the sound effects. In particular, he notices the grammatical features in the sonnet that underline the universal aspect of the described phenomenon (Hlebec 1987: 132). Interestingly, Hlebec refers to his informed translation as "Version A" and at the end of the paper offers "Version B" - an "adulterated", as he calls it, example of what Shakespeare's sonnets usually look like when translated. What is not stated in the paper is his own misgivings that, paradoxically, the second version is "somehow more likeable" (Hlebec 2012, personal communication). It seemed to me that CPT existed to answer why certain translations "sound better". Nevertheless, at the very start I was baffled by the fact that, while other Serbian educated native speakers agreed that the second version

2 This article is a revised version of a chapter to be included in Louw and Milojkovic (2016). At the time, this initial plan did not materialise, but I am using this opportunity for the second time to acknowledge Professor Hlebec's encouragement, support and professional advice regarding chapters 7 and 8 of the book. The material was gathered and written up in 2013 (this must be borne in mind when it comes to references to students and corpora). I would also like to express my deep gratitude to my then students, Višnja Krstić, Slađana Anđušić and Suzana Subotić, who took the trouble to participate in my analysis of prof. Hlebec's translations. 
"sounded better", I, a native speaker of Russian, was delighted with the first.

This is the sonnet followed by the two versions:

Sonnet 129

The expense of spirit in a waste of shame

Is lust in action; and till action, lust

Is perjured, murderous, bloody, full of blame,

Savage, extreme, rude, cruel, not to trust,

Enjoy'd no sooner but despised straight,

Past reason hunted, and no sooner had

Past reason hated, as a swallow'd bait

On purpose laid to make the taker mad;

Mad in pursuit and in possession so;

Had, having, and in quest to have, extreme;

A bliss in proof, and proved, a very woe;

Before, a joy proposed; behind, a dream.

All this the world well knows; yet none knows well

To shun the heaven that leads men to this hell.

\section{Version A}

Trošenje snage u rasapu srama

Pohote strast je; $u$ dejstvu strast biva

Krvava, zverska, reč zadatu slama

Svirepa, lažna, zla, pomamna, kriva,

Slađena tek je - već prezrena nama',

Tražena besno, a čim dostignuta

Mržena besno, poput kakvog mâma

Stavljenog da se sludi ko proguta.

Isto u težnji k'o imanju luda,

Pomamno tražeć, sežuć, tažeć htenje,

Kušana - sreća, okušana - huda,

Pre žuđen ushit, posle priviđenje.

Svet dobro zna sve to, no ne zna kako

Izbeći raj što vodi u taj pakō 
Version B

Trošenje snage kad nestaje stida-

To pohota je; i dok ona traje

Divlja je, krvava, zakletvu kida,

Nepouzdana, svirepa i zla je.

Po užitku kratkom, istoga trena

Prezrena je, uz puno mržnje lude,

Poput nekakvog mamca postavljena

Da onaj ko proguta sluđen bude.

Pomamna kad traži i kada ima,

Mahnita kad seže i kada ganja,

$U$ dejstvu čini ljude blaženima

A utažena - tek je pusta sanja.

To zna svet dobro, ali nije lako

Izbeći taj raj što vodi u pakō.

The question I asked seven educated native speakers of Serbian was which version they liked better. I did not ask them to compare either version with the original, but to focus on the difference between the two translations. The feedback I got focused mainly on syntax. They claimed that in Version A it was "archaic", "more suitable for Shakespeare's times", while Version $\mathrm{B}$ was pronounced much more appealing to the modern reader. The same went for some "archaic" lexical choices. As syntax has to do with corpusderived subtext, I decided to compare both versions subtextually. As for lexis, could there be any collocational mismatches in Version A due to the effort involved in conveying Shakespeare's manifold nuances? Could the whole first version be suffering from artificiality? And why could I, a Russian native speaker, feel only the translator's mastery?

This characteristic comment on both versions came from Višnja Krstić, then a third-year student at the Department of English, University of Belgrade:

I agree that Version A conveys meaning better, whereas Version B sounds more natural. In my opinion, Version A sounds like a word-for-word translation; there is no flow. However, Version B sounds as if it was originally written in Serbian. 
The research question of this paper is, therefore, why Version B was regarded by all interviewees as "more appealing" than Version A. Theoretically, it could also be extended to which version of the sonnet's translation should be evaluated as the better one of the two, taking into account not only semantic accuracy, but also naturalness. However, this paper cannot deal with such an issue in sufficient depth, except to acknowledge that the former question must have a bearing on the latter.

The deployment of the Corpus of Contemporary Serbian for this purpose needs clarifying. A balanced reference corpus of a language is a representative sample of a speaker's accumulated linguistic experience. Syntactically, poetic texts differ from prose. There is no poetry corpus of the Serbian language available, therefore precedents in poetic language could not be empirically established. Still, a departure from syntax that is not normally found either in prose or in poetic discourse must influence the speed of processing, especially if lexical collocations create unusual states of affairs. Besides, the Corpus of Contemporary Serbian is still insufficient in size for a full-scale study, given the flexible word order of Slavic languages as compared to English. The present study is offered as an example of how CPT may assist translation into Serbian, and certainly not as definitive judgement. If a representative poetry corpus of Serbian was available, both reference corpora would have been consulted. In any case, a poetic deviation from prose syntax would have to be found frequently enough in poetry in order to be pronounced easily comprehensible. When it comes to lexical collocation, the question is not so much whether a lexical choice is or is not unusual, but whether a collocation thought up for the purposes of translation creates, in the mind of the reader, the state of affairs desired by the translator. Finally, any deviation from the norm in a poetic text entails foregrounding. Ideally, its translation should employ foregrounding if and only if it reflects the meaning of the original.

\subsection{Evaluating the first syntactic whole}

In order to answer the research question, the first syntactic whole will be evaluated in detail.

"Word for word" and "no flow" would suggest unnatural subtext. For the benefit of subtextual analysis I divided the original sonnet into syntactic wholes - the shortest that were possible. I did not succeed in the latter attempt too well, as Shakespeare's syntax is at its most condensed from the middle 
of the second line till the end of line 8. Then, I compared each syntactic whole with its semantic equivalent from both versions. As I was primarily interested in subtext, I removed the formal indication of beginnings and endings of separate lines, making the sentences resemble prose. Subtext is at the root of a language, therefore a poem written by a native speaker will break language rules only for the purpose of foregrounding. If a deviation from the norm in a translation does not result in foregrounding consistent with the original poem's message, it probably should not have occurred at all, particularly if it is significant. With translated texts the question of intended meaning is solved by the original text.

Th' expense of spirit in a waste of shame is lust in action Trošenje snage u rasapu srama pohote strast je (Version A) Trošenje snage kad nestaje stida - to pohota je (Version B)

In Version A, after the prepositional phrase, "lust in action" is translated as "passion of lust", and the nominal predicate comes before the copular verb, which has been moved to the end of the sentence. The displacement of the verb is influenced by the rhythm. Alliteration abounds. The word order in the nominal predicate is also reversed: the Serbian equivalent of 'lust' - pohota is emphasised by its initial position in the line, but in everyday language it would be more natural for it to come after strast ('passion'). Pohote is the genitive case of pohota and modifies strast in the nominative, which is the head of this noun phrase. In Serbian it is more usual for nouns in the genitive to follow nominative nouns they modify, and for the copular verb to precede such a noun phrase (e.g. jeste strast pohote).

That the structure pohote strast je is uncommon in Serbian prose can easily be proved with the help of the reference corpus. I entered the search string $[a-z]+e[] \mathrm{je}$, which is the equivalent of $* \mathrm{e}+*+\mathrm{je}$. In the first 1,000 contexts I found only three structures containing two nouns followed by the verb form je ('is'). They were shvatanje bolesti je ('understanding of the desease is'), lice pobedenoga je ('the face of the defeated is'), and lice pobednika je ('the face of the winner is'). None of these begin with a noun in the genitive followed by a nominative noun. On the contrary, they all consist of a nominative noun followed by a genitive one. The $-e$ ending is an indication of the neuter gender of the first noun, not of the genitive case.

Still, this can hardly create an interruption. Such a deviation from prose word order is not at all uncommon in Serbian poetry, and, in practice, there is no danger of impeded understanding. What may cause discomfort in the 
reader is the syntagm pohote strast ('passion of lust'). Indeed, 'passion' may be considered a hypernym of 'lust', and, in this context, the two may be used interchangeably in both English and Serbian. The use of strast ('passion') is justified as it substitutes pohota ('lust') in the second half of line 2, no doubt for valid versification-related reasons: not only is the word monosyllabic, but its three-consonant beginning supports alliteration that the translator was at pains to re-establish in Serbian. However, in the domain of subtext, the translator has created an unusual (poetic) grammar string that amounts to a reversed (from the point of view of everyday language) relationship of two nouns that, when clarified, may be taken to mean the same as either of these nouns on its own. As a whole, the lexicogrammatical collocation pohote strast je is a complication.

In Version B this complication does not occur. Lines 1 and 2 are separated by a dash - this is a natural barrier, preparing the reader for the explanation which is to follow. The content of the first line is summed up in to ('that'), after the dash. The translator then proceeds to call lust 'lust', and not 'passion of lust' (pohota and not pohote strast). "Is lust in action" is translated as to pohota je ('that is lust'). The copular verb follows the nominal predicate, consisting of one word, and has to ('that') as its subject, rather than the whole of line 1 , as in Version A. What has been lost is the repetition of the word 'lust' in line 2 and an opportunity for using the noun strast ('passion') for alliteration purpuses.

Let us now compare versions $\mathrm{A}$ and $\mathrm{B}$ in the domain of lexical collocation. "Th' expense of spirit" is translated as trošenje snage in both versions. Version A's equivalent to "in a waste of shame" is u rasapu srama, where the preposition is followed by a noun in the locative case and a modifying noun in the genitive. Rasap is a rare word, adequate because it is generally used in elevated discourse - I found 16 instances of its use in the then 113-million-word Corpus of Contemporary Serbian, ${ }^{3}$ which support this usage:

3 Since there were two interim versions of the corpus between 2011 and 2013, I must have used the one close to that which is currently available: SrpKor2013. No changes have been made to it since January 2013. 
Marija Milojković: Contextual Prosodic Theory Applied to English-Serbian Poetic...

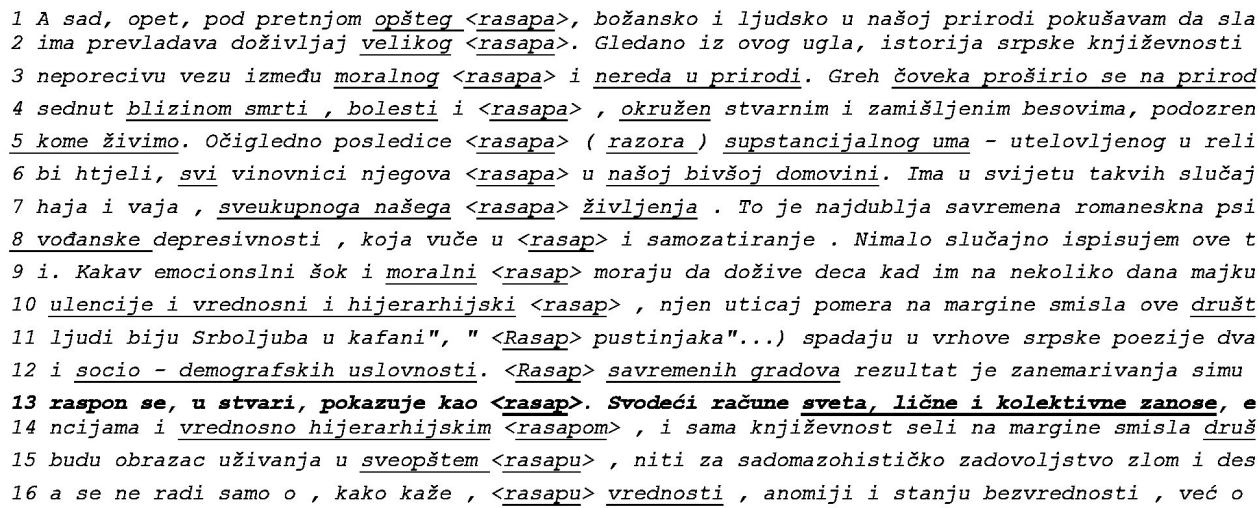

Rasap is used in all 16 contexts to draw attention to waste that is great both in its scale and mindlessness. The nominative noun is followed by a genitive noun (as in Version A) in four lines out of sixteen (the genitive is expressed in the English original by the prepositional phrase "of shame"). The genitive noun collocates of the noun rasap in the reference corpus lines all imply something of value:

- line 5: supstancijalnog uma ('of a mind of substance')

- line 11: pustinjaka ('of hermits')

- line 12: savremenih gradova ('of modern cities')

- line 16: vrednosti ('values')

A claim can be made that the translation in Version A sounds odd because the Serbian noun rasap usually has positive collocates, while sram ('shame') has negative associations. Still, this is nothing but proof that the noun phrase "in a waste of shame" has been adequately translated: shame must have been viewed by the poet as a desirable quality, forestalling expressions of lust. ${ }^{4}$ As for rasap, the word is relatively rare - this is shown by the presence of only 16 contexts in the Corpus of Contemporary Serbian - and sufficient knowledge of its behaviour cannot be drawn from the corpus. However, the concordance shows that the word rasap is used when describing general and long-lasting states affecting groups and societies; when it affects individuals (context 9), society is to blame. In context 4 it is not clear what kind of waste is discussed in the individual's life - it is possible that it is the consequence of his being born into a certain class

4 For a discussion of the meanings of 'shame' and the translator's choice of lexical equivalents, see Hlebec (1987: 132-134). 
of people. On the other hand, in the translation this rare word is used to describe an individual state, albeit universal, and a short-lasting one.

In Version B, the equivalent of "in a waste of shame" is kad nestaje stida ('when shame disappears'). In contrast to u rasapu srama (which contains a rare word unusually used), kad nestaje stida is immediately understandable. This is a subordinate clause, fairly frequent; nestaje is the third person singular present tense form of a fairly frequent verb. Stid is very similar in meaning to sram and is considered its synonym. In fact, out of the 435 instances of the form stida in the Corpus of Contemporary Serbian (this form was searched for in order to satisfy the definition of corpus-derived subtext, and to narrow down the sample obtained), one did contain the exact collocation nestaje stida. This is a quote from Vuk Karadžić, the founder of modern Serbian - which makes the example all the weightier:

145. obiljkama.txt:

Srbi pripovedaju da je ono crveno od pre veće bilo, pa onda svakoga dana biva manje jer nestaje <stida> među ljudima (Vuk, Rječn., s. V . ) . SUNCOKRET Sonnenblume? helianthus annuus, . Suncokret

What remains to establish is the difference in usage between the two Serbian equivalents of 'shame': sram (Version A) and stid (Version B). The old expression ni stida, ni srama, which can be translated as 'some have no shame' shows that there might be a difference (why use two words where one would suffice):

\footnotetext{
1 Đinđić i njegova stranka ističu na stub <srama>, a državu tretiraju kao svoj plen, rekao je na 2 cvet $i$ trn. Ako. Ona je uvek žena bez 〈srama〉 a muž joj sunce. Iako joj svakog proleća dolaz 3 Pešić. Aleksandra Brkić Zid plača i zid <srama> Akademska rasprava ispred zida plača Studenti 4 nešto! " "Mislim da nemate ni stida ni 〈srama〉, ako baš hoćete da znate šta mislim ", rekla j 5 vati vaše telo. Kod Radmile taj osećaj 〈srama〉 bi pojačan i jakom grižom savesti. Tek u tom tr 6 njala nazore. Bol je postajao teži od <srama〉. Bolničarka je podelila starim ljudima u odelj 7 rniji, Huanov teret će postati simbol <srama> cele jedne zemlje, piše londonski " observer ". 8 raslo interesovanje " klijenata ". Z̆ig 〈srama〉 Često obeležavana žigom srama, kao kopilad," de 9 ednje pare $i$ vraćao se kući, pun jeda $i$ <srama>. Četvrte ili pete večeri pođe mu za rukom da $s$ $10 \mathrm{koji}$ se stavljaju, bez razloga, na stub 〈srama〉.. Čitanje zahteva praćeno je stalnim povicim 11 najveći varoški dasa!? Kako bi mogao od 〈srama da se pojavi na ulici!? A i ja sam mu one no 12 o razvodu govorilo šapatom, krišom, sa određenom dozom 〈srama〉 - danas je situacija uveliko d 13 e tako postiglo stavljanje Irana na stub <srama>, gde je ovde poodavno stavljen kao deo osovi 14 o dvostruko slovo $S$ nosi kao " Kainov žig 〈srama ". Gras Izraelcima poručuje da svoja dostig 15 i i nemo posmatrati taj separatistički hod 〈srama> i beščašća zvaničnika u Crnoj Gori i uvlač 16 za sredinu u kojoj se bez ustručavanja $i$ <sramà (i bez ozbiljnijih posledica) javno mokri na 17 Ali sad svako može da greši otvoreno i bez 〈srama〉, i da živi i napreduje. I zato je svako ko 18 ednu, Sunjevića na drugu stranu. Kroz suze <srama〉 i gneva video je Nenad još dugo visoku pri 19 integracija je znak degradacije i obesčašenja, 〈srama > i inferiornosti, kao što je za moju 20 Gospod je rekao: 'Kad nogama izgazite ruho 〈srama〉 i kad dvoje postanu jedno, i kad muško sa
} 
Marija Milojković: Contextual Prosodic Theory Applied to English-Serbian Poetic...

1 je nesvestica od sasušene kamilice $i$ od - 〈stida〉. A evo kako je sve to bilo. Ta prokleta stva

2 i beše slab $i$ mekušan čovek umre od tuge $i$ 〈stida〉, a ona tada dovede u zamak svoj grešni plod

$3 \check{z ̌ i d, ~ u n e o ~ c e l o g ~ s e b e, ~ b e z ~ u l e p s ̌ a v a n j a, ~ b e z ~\langle s t i d a\rangle ~-~ a ~ t o ~ j e ~ u p r a v o ~ o n o ~ s ̌ t o ~ n a s ~ i n t i m n o ~ i ~ p o v e ~}$

4 lične koristi, po unutrašnjoj potrebi, bez 〈stida〉, bez griže savesti, čak i bez straha. Sve š

5 pravi društvo. Smejao se kapetanu, koji od 〈stida〉 crveni, a vikao je da nagone tela treba zad 6 da to devojče nešto oseća prema njemu, od 〈stida〉, crveni. Mogao bi joj po godinama otac biti!

7 saginjao, $i$ njegovo se meso od hladnoće $i$ 〈stida $\rangle$ crvenilo. Čeprkao je pod kamenom u vodi, is

8 u njemu lepog Crnogorca - ona bi umrla od 〈stida〉. Čak ni on to ne sme da zna. Ni jednim gesto

9 nekadašnjih đaka koji bi propao u zemlju od 〈stida〉 da mu se spomene šta je nekada šarao po $k$

10 da bude u kući, ne može da je gleda od 〈stida〉, da ona njega gleda posle petnaest godina, pa

11 golišave, nasmejane vragolije $i$ ne porumene od 〈stida〉. Dole su vodoskoci skakutali, umorno $i$

12 pred crkvom dovodila ga je do očajnog besa $i$ 〈stida〉. Doznao je da ima sina, $i$ od toga dana b

13 boli svakog odvažnika skromnosti ili ovna 〈stida〉. Eto, tako me je tog jutra grof biskup Turn

14 mišići na obrazima tresu se pod crvenilom pravog 〈stida〉. Gospa Nola ga pogleda, i nešto u nj

15 Kada ponovo otvorim oči, sklopljene od 〈stida〉, gospođica Edit već leži na našem otomanu, po

16 oseća Andra, pa je i njega stid zbog tuđeg 〈stida〉. Hoće nečim i sebe i Aćima da uteši, a cig

17 Musenalmanacha, premirući od nerazumljivog 〈stida $>i$ čudne bojazni. Pretvarala se da čita a u

18 kamenjem $i$ blatom. U meni je sve vrilo od $\langle\underline{\text { stida }} i$ gneva $i$ kad mi je smešna situacija postal

19 oći se zamagle, ispuni ga svoga ono osećanje <stida> i gneva na samog sebe, osećanje koje ko

20 je u ovoj staroj srpskoj deregliji reda, i ponosa. i 〈stida>... i,i, i lepote, da $i$ lepote je

The collocates of the form srama imply public shame in the majority of the contexts: stub srama ('mark of shame', lines 1, 10, 13), zid srama ('wall of shame', lines 3,8 ), žig srama ('the mark of shame', line 14). Although lines 5, 6, 9, and 18 show that sram as an individual feeling also exists, it is more frequently used in social contexts rather than private (lines 7,11 , $12,15,16,17,19)$. On the other hand, stid is always used for describing inner, private emotions, especially in contexts of sexual relationships or even their remote possibility (lines $6,8,9,11,12,14,15,17$ ). In lines 5 and 7 exposure of one's body causes stid. Sram is a consequence; stid is a preventive quality. Sram may be used in the context of political games, while stid is the feeling that may overwhelm a person in the context of temptation. Stid is what a person is expected to feel to prevent him or her from experiencing sram later on, so to speak.

All in all, when it comes to $u$ rasapu srama (Version A), the word rasap in Serbian seems to imply a general and long-lasting waste, and sram in this context seems to support its social, not individual, connotation. ${ }^{5}$ On the other hand, kad nestaje stida is a frequent structure as well as an existing lexico-grammatical collocation, including the collocate stid, which is perhaps more appropriate in contexts of sexual temptation. The

5 I do not claim that the modern reader is aware of these nuances. I merely state that a lexical collocation in which both collocates are used in a type of context different from the type where they are normally used (and create different states of affairs in the reference corpus) may not be spontaneously absorbed. 
latter therefore seems to be a more appropriate translation, given that neither translation offers underlying meanings that are present in the original.

The difference between sram and stid was pointed out to me by student Sandra Anđušić: "I feel that stid has a milder connotation, while sram is more intense." It is possible that Sandra felt that sram was more intense than stid because public shame is felt as more irreparable and hurting. Given corpus data, I have not found that stid is less intense, rather that it is centred upon a different kind of relationship: society is not involved. ${ }^{6}$

\subsection{States of affairs and subtext in the rest of the two versions}

In her feedback Sandra Anđušić also points to another pair of alternative lexical choices. "Lust/ is perjured" is translated differently in Version A and Version B. Version A says reč zadatu slama (literally 'breaks the given word'), whereas in Version B it is zakletvu kida ('breaks (literally 'tears') the oath'). Zadata reč ('a given word') is less firm a promise in Serbian than zakletva ('oath'), which is obvious enough not to be in need of corpus evidence. Sandra points out that the verbs used with these may also not be identical in intensity:

The second one is slama versus kida. Slama sounds, to me, less violent and it has a sort of metaphorical meaning, usually used with something unintentional or breaking vows or promises. However, kida has a more vicious sound to it and it reminds me of mindless destruction, or animalistic behaviour.

These qualities are more opaque to intuition than the difference between a given word and an oath and are worth checking:

6 These findings explain a modern reader's possible reaction to the expression $u$ rasapu srama. Etymologically, it seems that both Serbian equivalents of 'shame' work (http://febweb.ru/feb/ushakov/ush-abc/18/us457304.htm?cmd=0\&istext=1, https://lexicography. online/etymology/vasmer/c/copom, accessed on $5^{\text {th }}$ August 2020). 
Marija Milojković: Contextual Prosodic Theory Applied to English-Serbian Poetic...

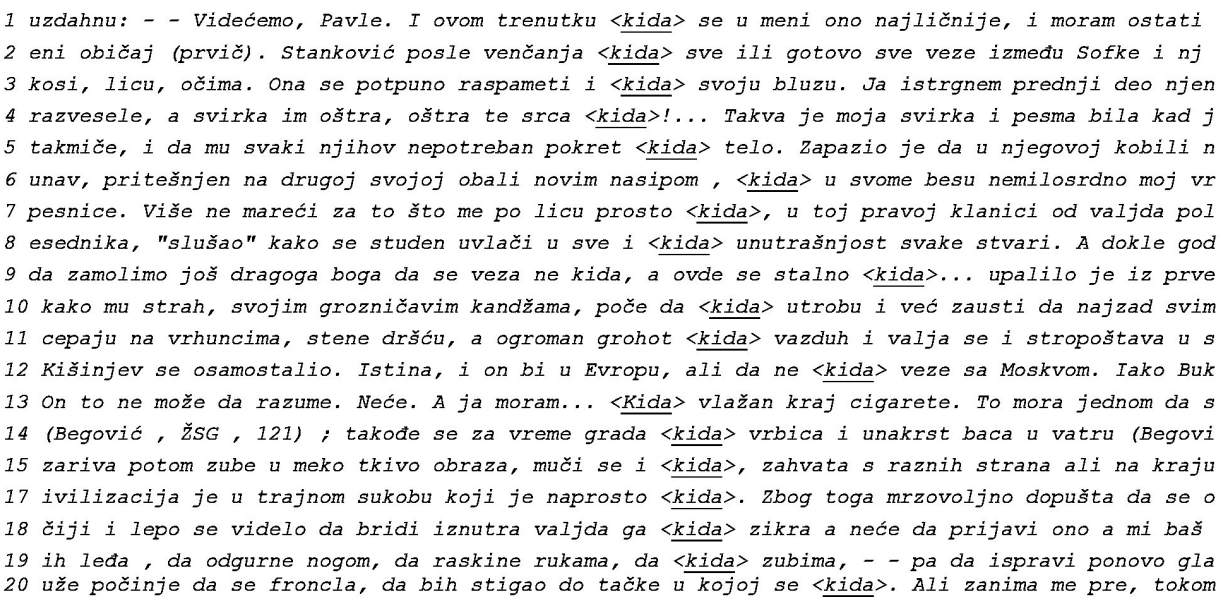

These are twenty contexts of the verb form kida that first came up in the corpus. In lines $3,5,6,7,8,13,14,15,19$ and 20 (50\% of the lines) the tearing is literal. In lines $2,9,12$ and 17 what gets broken is ties and connections. In 1, 4, 10 and 18 a person is torn by a strongly felt emotion, in line 8 by physical cold, in line 11 the air is torn by noise. In line 19 the tearing with one's teeth is metaphorical and necessary for survival, but the collocate 'teeth' relexicalises (i.e. revives) the physical aspect of the verb's meaning.

Out of the 177 contexts of the form kida yielded by the Serbian corpus, in one the verb is co-selected with the collocate reči ('words'):

\footnotetext{
a analizu pak - kao što ćemo uskoro videti - najzanimljiviji je slučaj kada se pri izmeni reda reči <kida> najuža sintagmatska veza, što neminovno uslovljava pojavu nove pauze : "Svesku daj sestri ? svoju
}

What is broken in this context is the syntagmatic relation, which is due to the change in the word order (Serbian). These are the contexts of the verb form slama: 
$1 \mathrm{kad}$ se uhvati s njime u koštac, kako ga onaj 〈slama〉, mrvi, satire i obara, pokazujući svoju sn 2 rane. *** Boga ti božjeg, šta se to s neba <slama>! Zar u poslednjem času psuješ? Uvek si pijan 3 ljudi su jednostavno zaboravili kako grip 〈slama〉 i baca u krevet kada je u punom naletu, mada 4 osti $i$ svoje savesti ili da se neprekidno <slama između zahteva svog unutarnjeg bića i zahteva 5 igra u ovoj azijskoj zemlji. Brzo vođstvo "〈slama> "Kazahe. Igrači plaćeniji nego u Srbiji Ka 6 plavuša. Ksenija pajčin Za nju se šuška da <slama> muška srca kao slane štapiće i da nema tog b 7 og džet-seta $i$ stekla titulu devojke koja " 8 tako da veliki broj suđenja i autodafea brzo 〈slama> nagli razvoj. Poslednji su događaji poznat 9 prema izveštaju AFP iz Tokija, na kojima se <slama> ovaj mamutski sistem koji je celom svetu pr 10 se ustremi ka pobedi. Umesto da nastavi da <slama protivnicu u visokom ritmu, dozvolila joj j 11 Sa XVIII vekom, u Kini, kao i u Evropi, <slama>se biološki stari poredak, skup prinuda, prepr 12 uzrokuješ nečiju bol? U ovom filmu ta tema <slama> srce, jer je glavna junakinja spremna da iz 13 dečaka. Sada sam opet tu, u revoluciji koja 〈slama svu tu tišinu, u zemlji kojoj će uskoro bi 14 karijeri sa nepokolebljivim inatom iznova <slama> tabue i preispituje postavljene standarde u $15 \mathrm{kao}$ da se nista ne događa, stari poredak se <slama> : tradicionalna ustrojstva poljoprivrede i 16 prirode $i$ prividne moralnosti koja se lako 〈slama〉 u određenim okolnostima, što se ponajbolje 17 trgovine $i$ delatnosti. Tada sve počinje da se <slama〉, vrhunac krize se dostiže, vekovni trend 18 ako plaše, skoro su potpuno eliminisane. Grip 〈slama Zanimljivo je da mi imamo otpor i prema

19 ljudi, ali teret godina njih, očito, najlakše <slama〉, a da im se pred sudnji čas niko ne nađ 20 holozi, izrazito individualan. - Kriza nekoga 〈slamà, a nekoga jača, tako da odgovor na pita 21 Poraz jako teško podnosim $i$ u tom trenutku me 〈slama〉. Ali mi $i$ ukazuje na potrebu da još $k$ 22 iodu posle 1961. godine "ravnoteža se potpuno <slama> " (B. Krstí́), a srpsko stanovništvo se 23 egove moći i muževnosti Karla Bruni Žena koja <slama〉 muška srca, rokerka sa gitarom, nekadaš 24 stivala u Bijaricu), zastupa stav da publiku "<slama>" nametnuti izbor, pa otuda popularnost 25 gan "u ormaru" ili, pak, nešto iskustveno novo <slamà njegovu nenasilnost? Da li, naime, kod 26 virulentnost uzročnika toliko izražena da uvek <slama odbrambene snage organizma. A takvih b 27 pripremi svu logistiku za našu evakuaciju, da <slama> otpor Britanaca koji su se protivili nj 28 poslanika, o stranačkoj "gvozdenoj ruci" koja <slama> parlamentarizam i predstavljanje naroda 29 lanicama evrozone, kao u Irskoj koja se takode 〈slama pod posledicama svetske krize, govori 30 i koja na kraju tragično pobeđuje. Život se <slama> pod pritiskom ubistvenih okolnosti u tren 31 a svaki uticaj. Nasilje priznaje volju, ali je <slama>. Prijetnja i zavođenje djeluju tako št 32 sličnih domaćih zadataka". Osećaj odbačenosti "<slama" srce Kada saznamo da se nekom ne dopa 33 edice koje je ovaj rat ostavio na ovim ljudima <slama srce. Molim se Bogu da ono što su ovi 34 bi bez nje bio nemoguć. Tvrdi zakon rata se ne <slama u sudaru sa nemoćnom subjektivnošć ko 35 ne bih bio ovo što sam sad. Da li Vas nesreća <slamà? Video sam u različitim kulturama da $s$

The form slama seems to be rarer than kida, with its 35 occurrences in comparison with 177 of kida. Only in the first two lines is there any indication that the verb form is sometimes used literally, in its meaning of 'break'. In line 1 , the verb is followed by three more verbs whose superordinate may be 'destroy'; however, even the wider context available in the Corpus of Contemporary Serbian does not make it clear whether this is not definitely a metaphor. In line 2 the meaning is close to the English verb 'thunder', referring to noise made by weapons. In the rest of the lines, the verb form is used delexically (i.e. figuratively, not in its literal meaning) throughout:

1. Srce ('heart') is the object of the verb in lines $6,7,12,23,32,33$.

2. A person (their system of values, resilience, will etc.) is (being) 'broken' under pressure in lines 4, 19, 20, 21, 24, 35.

3. A good quality of a person or system is 'broken' (i.e. defeated) in lines 25, 28, 31.

4. The opponent is 'broken' (i.e. defeated) in sports in lines $5,10$.

5. A disease 'breaks' (i.e. incapacitates) one in lines 3, 18, 26. 
6. (The development of) an order or system is broken in lines 8,9 , $11,13,14,15,17,22,29,30,34$.

On the whole, slama seems to be used delexically much more frequently than kida; it does not refer to destroying connections, but to defeating people or their principles, as well as (positive) traditions. The emphasis is on the consequences, whereas in the contexts of kida it seems to be on (the violence of) the process. Slama may be used positively (as in the breaking of taboos in line 14, or defeating opponents - on the basis of only two lines, 5 and 10, we may conclude that the verb is not used of the home player(s) - clearly, more evidence is necessary). An old order being replaced by a new one is not necessarily destructive in the long run - on the contrary, this is a historical necessity (lines 11, 15). A flu may incapacitate, but only temporarily. However, where the use of slama is negative, what we are left with is the feeling of frustration at unlawful violence and the lack of protection of the victim.

I am inclined to conclude that Version B (zakletvu kida) is a better choice than Version A (reč zadatu slama). Slama is hardly justifiable in the context of zadata reč ('the given word'). It is often used delexically in a wide range of situations, but the translation does not evoke any of the states of affairs present in the concordance, and, therefore, the association between the noun phrase and the verb form could be seen as mechanical, thought up for the purpose of translation. The same argument could be used to comment on zakletvu kida in Version B, but I believe the situation is saved by the physical associations created by the verb form, reminiscent, as the student pointed out, of animalistic instincts involved in the setting of the sonnet. In the concordance of kida there is a context of intercourse (3), as well as several delexical uses ( $50 \%$ of the concordance, as noted above). Also, there are contexts of breaking ties and connections. Slama seems less likely be used in the context of sex, it is too delexical. Interestingly, none of the classics like Andrić, Ćosić or Crnjanski seems to have used it in the texts that make up the Corpus of Contemporary Serbian; generally, the texts where this verb form is used are not literary, with one or two exceptions. Finally, while kida means 'destroys', slama has the additional meaning of 'defeats', especially when the act is unfair and leaves victims behind it. 
Let us now briefly look at the other sections of sonnet 129 and versions $\mathrm{A}$ and $\mathrm{B}$, with the syntactic wholes uninterrupted by endings/beginnings of lines:

and till action, lust is perjured, murderous, bloody, full of blame, savage, extreme, rude, cruel, not to trust, enjoy'd no sooner but despised straight, past reason hunted, and no sooner had past reason hated, as a swallow'd bait on purpose laid to make the taker mad;

u dejstvu strast biva krvava, zverska, reč zadatu slama, svirepa, lažna, zla, pomamna, kriva, slađena tek je - već prezrena nama, tražena besno, a čim dostignuta mržena besno, poput kakvog mama stavljenog da se sludi ko proguta. (Version A)

i dok ona traje divlja je, krvava, zakletvu kida, nepouzdana, svirepa $i$ zla je. Po užitku kratkom, istoga trena prezrena je, uz puno mržnje lude, poput nekakvog mamca postavljena da onaj ko proguta sluđen bude. (Version B)

There is no need to resort to the Serbian corpus (given the amount of work involved) to observe that there are several syntactic (and therefore subtextual) patterns here that are not common in contemporary Serbian. For example, slađena tek je ("enjoyed no sooner" in Shakespeare) consists of a form corresponding to the English past participle followed by the temporal adverb tek and by the third person singular verb form je of the infinitive biti ('to be'). There is a fair number of examples of the pattern *ena tek, but none were yielded by the searchline *ena tek je, as the usual (everyday) pattern would be tek je slađena (only one example of it was found, tek je završena, meaning 'just finished').

Tražena besno... mržena besno preserves the parallelism of "past reason hunted... past reason hated", but introduces too many verb forms corresponding to English participles, ${ }^{7}$ and this is known not to be a feature of contemporary Serbian. The saved space does not seem to help matters, especially since these two "participles" are separated by a third "participle" construction (a čim dostignuta - "and no sooner had"). Dostignuta is not

7 In Version A, the Serbian form corresponding to the English past participle is the one termed in Serbian glagolski pridev trpni, and the form corresponding to the English present active participle is termed glagolski prilog sadašnji. For brevity's sake, such Serbian forms will be referred to as "participles". 
a rare verb form in Serbian - there were 69 occurrences in the Corpus of Contemporary Serbian - and the "participle" form itself is very much present in the language (e.g. zategnuta, užasnuta, etc.). The culprit is čim ('no sooner' or 'as soon as'), because in everyday language it is followed by the verb form je. Indeed, in the single context yielded by the searchline cim *uta, the form ending in -uta modifies a noun, while there are no lines where there is an end-stop after čim *uta.

podneti zahteve za vraćanje mandata <Čim pomenuta〉 odluka bude objavljena. Zahtevi će, kako kaž

In any case, the conglomeration of "participle" structures must account for Version A "not sounding as good as Version B", according to the feedback provided by the seven speakers of Serbian consulted.

Version $\mathrm{B}$, although it does not preserve the parallelism "past reason hunted... past reason hated", retains fewer "participles" than Version A, and does not feature so much alliteration, employing a more naturally Serbian sentence structure. For example, the succinct "participle"-containing clause slađena tek je is replaced with the prepositional phrase po užitku kratkom ('after short-lasting enjoyment'). Similarly, the "participle" phrase mržena besno (the equivalent of "past reason hated") is replaced with the prepositional phrase $u z$ puno mržnje lude.

Student Suzana Subotić comments:

Besides the oddity of tražena besno and mržena besno, which has rather an English pattern, I also think that the third line in the second version is more acceptable in Serbian. The world order is closer to ours, which ensures better understanding and, at the same time, has a more profound impact on our emotions. Furthermore, if there's no oddity in this particular construction in English ("On purpose laid to make the taker mad"), then this shouldn't be the case in Serbian either (Stavljenog da se sludi ko proguta.). I am aware that this change in word order may occur for the sake of the rhyme as well, but the second version, although not capturing Shakespeare's exact meanings, still sounds better.

The same subtext-related problems in Version A (namely, odd word order and too many forms corresponding to English participles) and their relative absence in Version B are observed in the following sections of the sonnet's translations: 
Mad in pursuit and in possession so

Isto u težnji k'o imanju luda (Version A)

Pomamna kad traži i kada ima (Version B)

Version A actually takes time to decode, so hard did the translator try to condense the meaning of the original; Version B is understandable at once.

Had, having, and in quest to have, extreme

Pomamno tražeć, sežuć, tažeć htenje (Version A)

Mahnita kad seže i kada ganja (Version B)

The three shortened "active participles" in Version A call for the same comment as "participles" in lines 5-7, although the shortened form as such is not completely rare, as I found two prose contexts for the search line "žeć and one poetic context for the search line "žuć:

1 Ifigeniju na Tauridi, dušom svojom zemlju Grka 〈tražeć>, ili poput Ovidija u Tomima, razmišlja

2 adića - dobrovoljaca, pevajući narodne pesme $i$ 〈tražeć> pred dvorom $i$ Ruskim poslanstvom otetu

1 ane kante što je pretura vetar. Automobili bruje <kližuć> po kocki puta kao po ribama sura vod

As to Version B, here parallelism with the previous line is formed; although this is unwarranted by the original, it makes up for the missed parallelism of "past reason hunted... past reason hated" in this version.The repetition of kada ('when') may be taken to reflect repetitions in this section of the original.

A bliss in proof, and proved, a very woe

Kušana - sreća, okušana - huda (Version A)

$U$ dejstvu čini ljude blaženima (Version B)

Version A is again dependent on forms corresponding to English participles. The obsolete adjective huda ('bad', 'miserable', 'poor') is appropriate to poetic discourse - I also found 20 forms of it in the Corpus of Contemporary Serbian. 
The wording in Version B does not contain the contrast found the original: $U$ dejstvu čini ljude blaženima ('in action [it] brings people bliss'). Paradoxically, I like this line better than I can reasonably explain. I attribute it to the regular metre and the pleasant associations with the plural instrumental adjective blaženima ('filled with bliss'), as well as the naturalsounding word order. However, there is something about the prepositional phrase $u$ dejstvu ('in action', 'while in progress') that I find comforting, co-selected with what follows. $U$ dejstvu does not chunk pleasant states of affairs, or a positive semantic prosody, as a rule. Here are its 15 occurrences in the Corpus of Contemporary Serbian:

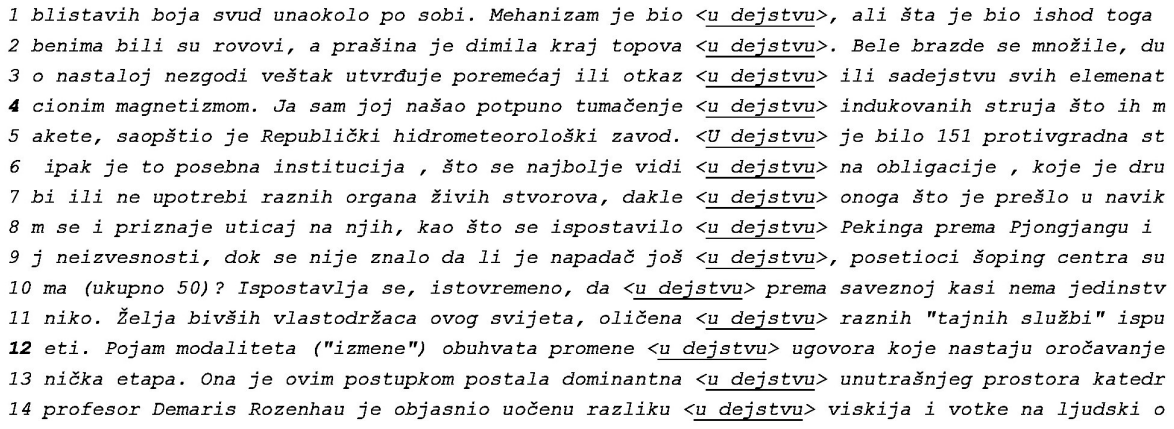

U dejstvu definitely carries a negative semantic prosody, which is either shown by the phrase's immediate collocates or by collocates that appear in its somewhat wider context. Indeed, only line 13 is completely free of negativity. Although there is no contrast in Version B, the translator managed, through negative semantic prosody, to convey the clash between the "act" and the "bliss", and it ought to be felt at some level by native speakers, if my 15 lines are representative of the language.

In Russian, however, I discovered that the prosody of $в$ действии, the Russian equivalent, is mixed: in technical and scientific contexts it tends to be positive; outside of these it can still be positive, but often is ironic or negative. For example, in the first four lines taken from the main corpus of the Russian National Corpus, the first context is technical and positive, the second and the third ironic, and the fourth negative: 


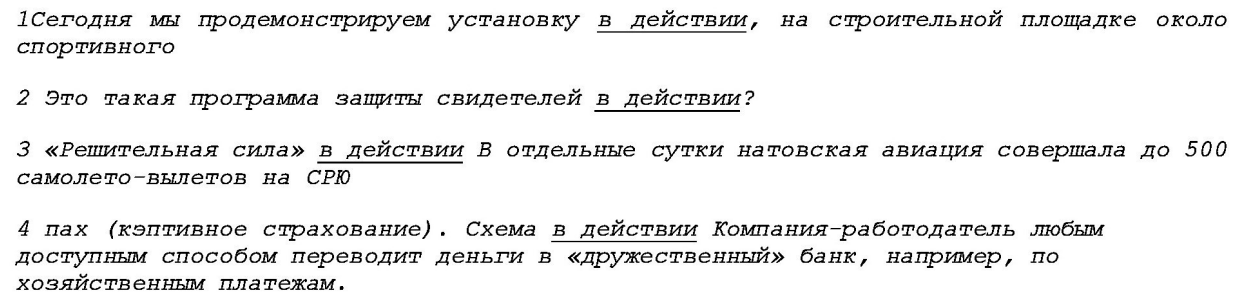

The first context is that of a construction site, the second mocks a witness protection programme, the third describes NATO's attack on former Yugoslavia (here it is not clear whether the journalist is sarcastic or outraged), and the last newspaper context deals with types of money laundering. Without further investigation into the semantic prosody of the Russian equivalent, I will conclude that the semantic prosody of $в$ действии in Russian depends on its (positive or negative) collocates, and that perhaps my liking of the line $U$ dejstvu čini ljude blaženima is a reaction to the positive collocate blaženima, whereas in Serbian the definite negative prosody creates the Shakesperian contrast described above.

Generally speaking, my liking of Version A, in which I disagreed with native speakers of Serbian, must be explained by the presence of forms corresponding to English participles in this translation. Whereas they are not common in Serbian, such forms are much more common in Russian, especially in literary writing.

Before, a joy proposed; behind, a dream.

Pre žuđen ushit, posle priviđenje (Version A)

A utažena - tek je pusta sanja (Version B)

In Version A, both parallel contrasts of this and the previous line have been retained. There are no verbs in these two lines, whereas in Version B both this and the previous line contain a verb.

In Version B there is no contrast within the line; however, the line forms a contrast with the previous one. Thus, the parallelism of the two contrasts is lost. What is retained is the elegance of Shakespeare; perhaps a literal transfer of his density can only be made at the expense of naturalness. It appears that, in Serbian, verbs are necessary in such transitions within texts for them to be processed more easily. Version B in this and the previous line reads more easily because of the presence of verbs, and, perhaps, because 
of fewer juxtapositions. On the other hand, my feeling is that Version A is more intense, due to fewer verbs, especially copular verbs.

In addition, this is student Suzana Subotić's comment on the translator's adding the adjective pusta ('empty') to the noun sanja ('dream'):

Here we have gradation, it is not just prividenje ('vision') or a dream, it is pusta sanja. Professor Hlebec took the liberty of adding the adjective pusta ('empty') for us to grasp the true attitude of the poet.

And finally, let us consider the couplet:

All this the world well knows; yet none knows well

To shun the heaven that leads men to this hell.

Svet dobro zna sve to, no ne zna kako

Izbeći raj što vodi u taj pako. (Version A)

To zna svet dobro, ali nije lako

Izbeći taj raj što vodi u pako. (Version B)

There is a slight variation in Version B: instead of saying 'no-one knows how to avoid the heaven that leads to that hell' (Version A), the translator says 'it is not easy to avoid...' This is how student Višnja Krstić explains her preference for Version B:

On the one hand, in Version A "yet none knows well" is translated as no ne zna kako, which is the proper translation since it fully transfers the meaning. On the other hand, ali nije lako (Version B) has a somewhat different meaning from what stands in the original text (literally 'but 'tis not easy' - M. M.). Nevertheless, this clause is more convincing to me - it carries the feeling of grief caused by the tempting nature of the human heart. In addition, it shows the ambiguous nature of man - we can easily distinguish right from wrong, but we often fail to resist following the wrong path. Therefore, Version B is also closer to readers on the emotional level.

It is worth adding here that I found no instances of no ne zna kako in the Serbian corpus, and 23 instances of ali nije lako. There were ten instances of ali ne zna kako (the conjunction no is more archaic, ali is common). 
Although the remaining sections of versions A and B have not been studied in as much detail as the first syntactic whole, the overall impression remains that syntax in Version B is far closer to the Serbian language than it is in Version A. My being a native speaker of Russian, in which syntactic structures from Version A are not unusual, especially in literary language, may explain my preference for Version A, in which I disagreed with all the seven speakers of Serbian that I consulted.

\section{Concluding remarks}

To conclude, if the only goal of the translator was to convey the meaning, the form, and the sound effects of the original poem, Version A would not have caused a less positive reaction than Version B on the part of seven out of seven educated English speaking Serbs who I consulted, all of whom were aware of the original and both translations. This may be due to Version A containing some syntactic patterns and lexical combinations which were inspired by the original text but might not be characteristic of Serbian. Nevertheless, student Sandra Anđušić did point out that:

...the first version shows the frustration of the original poem, the absurdity and the savageness of lust and love, as in the original, mainly due to words which are not so frequently used. Also, there are a lot of participles with shortened forms that are not as easily pronounced in a sentence, which only contributes to the overall air of the poem. The whole Version A requires more effort to read and to understand. It sounds more archaic, which is not a very bad characteristic when translating Shakespeare, since he is not a contemporary author, although his themes and motives are timeless. As for Version B, it seems to me a more "fluent" poem, since it somehow glides right off the tongue and is quite easy to read. This, perhaps, leads to easier identification with the emotions of the poem, since the reader can process it more easily. The constructions are much clearer and simpler. Also, there are three negative adjectives in the fourth verse, in contrast to five in version A and in the original. I found it less gloomy and depressing. 
Given the richness of Serbian syntax and vocabulary, the Corpus of Contemporary Serbian in its present form ${ }^{8}$ is still too small to conduct reliable investigations. A Serbian poetry corpus has not been constructed, which greatly reduces space for comment on poetic translation. However, on the basis of the comparison of Version A and Version B, it is clear that subtext used in a translation ought to have precedents in the target language, whether in its main or poetry corpus. Without such precedents the translator creates unwarranted foregrounding, not found in the original. This has a bearing on "poetic word order" - innovative reversals of word order in translation may impede comprehension.

Alliteration seems to interfere with a translator's choices as he or she may prefer lexis which may chunk odd or non-existent states of affairs in the language - such constraints are also imposed by the versification pattern. According to Louw (1993), when it comes to lexical collocation, a deviation from the norm in native speech will result in either irony or insincerity, both of which will be felt at some level by the addressee. Deviations from the norm as an attempt at poetic translation may produce states of affairs that do not exist either in the original text or in the target language. This will require an additional amount of effort on the part of the reader.

What must take precedence, truthfulness to form and content or "naturalness" of the final version? Boris Hlebec himself gave the following answer:

Sonnet CXXIX is an example of perfect matching poetic content with form, and it would be a pity not to have rendered something of that intricate and impressive versification pattern. However, it takes a reader fully aware of and ready to accept this iconicity in order to appreciate the merits of the translation that (at least partly) reproduces the pattern. The adulterated "popular" Version $\mathrm{B}$ serves as the second best alternative for those readers who are not tuned in to the poetic function and, being concentrated only on content, do not look for the meaningful repetition, internal rhyme, parallelism, sound symbolism, alliteration, and the motivated abundance of the "passive participles". Of course, such readers are opposed to the style when it is not smooth and find it unnatural when it only slightly deviates from the everyday

8 It comprises 122 million words, and this has not changed since 2013. 
syntax, although poetry in their native tongue abounds with such usages and the original is no less terse than the language of the translation in Version A. (Hlebec, personal communication)

It may not be complimentary for Version B to "sound better" than Version A - after all, as one of the students observed, the impression left by Version B may be more favourable partly because there are fewer lexical items, which are, in Shakespeare, all indicative of frustration, discomfort, and inner conflict. In addition, Professor Hlebec (personal communication above) insists that the original is "no less terse" than Version A, and, besides, that Serbian poetry does contain many examples of syntax used in that version. The former statement calls for a study of native speakers' reactions to the original; the latter for a poetry corpus. Still, the paper has shown that certain lexical choices in Version A might be considered less appropriate because they may not create the states of affairs intended when it comes to Serbian, while others were found particularly suitable. All in all, what is true to the original must not sound forced in the target language - and, when it comes to poetic translation, that is best checked not only in its reference corpus, but also in a representative corpus of its poetry.

\section{References}

Culler J. (1975). Structuralist Poetics: Structuralism, Linguistics, and the Study of Literature. London: Routledge and Kegan Paul.

Vitas, D. and M. Utvić. (2003). Corpus of Contemporary Serbian (version SrpKor2003). Copyright Human Language Technologies Group, University of Belgrade. (2012 and 2013) <http://www.korpus.matf.bg.ac.rs/ prezentacija/korpus.html>.

Jakobson, R. and L. G. Jones (1970). Shakespeare's Verbal Art in “Th'Expense of Spirit." The Hague: Mouton.

COBUILD (1998). Collins COBUILD English Dictionary. London: HarperCollins Publishers.

Hlebec B. (1987). Prevođenje Šekspirovog soneta 129 na srpskohrvatski jezik. Naučni sastanak slavista u Vukove dane, 16(3), 129-136.

Louw, W. E. (1993). Irony in the text or insincerity in the writer? The diagnostic potential of semantic prosodies. In: M. Baker, G. Francis and E. Tognini-Bonelli (eds.), Text and Technology: In Honour of John Sinclair, Amsterdam: John Benjamins, 152-176. 
Louw, W. E. and M. Milojkovic (2014). Semantic Prosody. In: P. Stockwell and S. Whiteley (eds.), The Cambridge Handbook of Stylistics, Cambridge: CUP, 263-280.

Louw, B. and M. Milojkovic (2016). Corpus Stylistics as Contextual Prosodic Theory and Subtext. Amsterdam: John Benjamins.

Milojkovic, M. (2013). Is corpus stylistics bent on self-improvement? The role of reference corpora 20 years after the advent of semantic prosody. Journal of Literary Semantics, 42(1), 59-78.

Wang F. R. and P. Humblé (2017). Corpus Stylistics as Contextual Prosodic Theory and Subtext by Bill Louw, Marija Milojkovic. Style, 51(4), 550-555.

Wittgenstein, L. 1922 [1960]. Tractatus Logico-Philosophicus, transl. D. F. Pears and D. F. McGuiness. London: Routledge and Kegan Paul.

Received: 23 October 2019

Accepted for publication: 23 June 2020

Марија Милојковић

\section{ПРИМЕНА КОНТЕКСТУАЛНО-ПРОЗОДИЈСКЕ ТЕОРИЈЕ НА ПРЕВОЂЕЊЕ ПОЕЗИЈЕ С ЕНГЛЕСКОГ НА СРПСКИ ЈЕЗИК}

\section{Сажетак}

Рад проучава два паралелна превода Шекспировог сонета 129 на српски језик (Хлебец 1987). Преводилац даје варијанту А, која верно преноси стилске нијансе оригинала и намењена је „компетентној“ публици, и варијанту Б, коју преводилац назива ,разблаженом“, али сматра да је она разумљивија за ширу публику. Међутим, сам преводилац осећа да је варијанта Б „некако допадљивија“. С овим утиском се сложило свих седморо образованих испитаника којима је српски језик матерњи, међу којима су била и три студента треће године Англистике. У раду се, применом контекстуално-прозодијске теорије и Корпуса савременог српског језика, траже могући разлози за то. На основу резултата може се закључити да синтаксички обрасци у варијанти А, будући ближи енглеском оригиналу него у варијанти Б, могу отежавати разумевање, и да је могуће да одређене лексеме у српском преводу не стварају исте асоцијације као њихови еквиваленти у енглеском оригиналу. Потребно је креирати репрезентативан корпус српске поезије да би се проверио 
став професора Хлебеца да је синтакса употребљена у варијанти А својствена српској поезији, па је, према томе, адекватна за превод овог сонета.

Кључне речи: корпусна стилистика, контекстуално-прозодијска теорија, колокације, семантичка прозодија, корпусни подтекст, превођење поезије 